\title{
Study on JV Virus in Patients with Colon Cancer Type Adenocarcinoma
}

\author{
Azadeh Haghi Navand ${ }^{1,2}$, Ali Teimoori ${ }^{2}$, Manoochehr Makvandi ${ }^{1,2 *}$, Nilofar \\ Nisi $^{1,2}$, Seyed Saeid Seyedian ${ }^{3}$, Nastarn Ranjbari ${ }^{4}$, Kambiz Ahmadi Angali ${ }^{5}$, Hadis \\ Keyani $^{1}$, Maryam Tabasi ${ }^{1}$, Keyvan Pourjabari ${ }^{1}$
}

\begin{abstract}
Colorectal cancer is the most repetitious malignancies with high mortality worldwide. JC virus (JCV) is ubiquitous Polyomavirus, with seroprevalence rates ranging from $70 \%$ to $90 \%$ in adult population. Recently the role of JCV have been reported in many malignant tumors worldwide. The association of JCV was reported in patients with colon and rectum cancers. Thus this study was conducted to evaluate the association of JCV DNA in patients with colon cancer type Adenocarcinoma. Material and Methods: A total of 120 formalin-fixed paraffin-embedded tissue blocks samples were collected including 20/40(50\%) males, 20/40(50\%) females patients with Colorectal Cancer(CRC), and 80 (50\% males, 50\% females) patients with benign tumor as a control. DNA was extracted for all the samples. Nested PCR was carried out for detection of Vp1/T-Ag junction genome in JCV genome by Nested-PCR assay. Randomly, PCR products of 6 samples were sequenced to analysis the partial JCV DNA. The phylogeny tree was constructed to determine homology identity with other JCV. Results: 4/40(10\%) samples of test group and 10/80 (12.5\%) of control samples were positive for JCV DNA $(\mathrm{P}=0.69)$. Out of 4 samples positive for JC DNA, 3(7.5\%) were males and $1(2.4 \%)$ female $(\mathrm{P}=0.29)$. The frequency of JCV DNA in age group $>50$ years was $4 / 32(10 \%)$, while in age group $<50$ years was $0 / 8$ $(0 \%)(p=0.29)$. Conclusion: prevalence of JCV DNA was among $10 \%$ patients with CRC and $12.5 \%$ benign tumors $(p=0.69)$. The distribution of JCV DNA was among $7.5 \%$ male and $2.5 \%$ female $(p=0.29)$. The frequency of JCV DNA was among $10 \%$ cases of age group $>50$ years and $0 \%$ of age group $<50$ years $(\mathrm{P}=0.29)$. The subsequent $\mathrm{T}-\mathrm{Ag}$ protein expression might explain the increased risk of colorectal cancer and requires further investigation.
\end{abstract}

Keywords: JC virus- colorectal adenocarcinoma- polymerase chine reaction

Asian Pac J Cancer Prev, 20 (4), 1147-1151

\section{Introduction}

Colorectal cancer (CRC) is the most recurrent malignancy, and third leading cancer with high mortality among men and women worldwide (World Cancer Research Fund, 2018). Most colon cancers are classified as adenocarcinomas and subdivided into low-grade and high-grade (Ugo et al., 2018). The pathogenesis of this tumor is not well known. Predisposing factors include Crohn's disease, celiac disease, hereditary genetic syndromes and dietary factors (Zaaimi et al., 2015). JCV is a polyomavirus that infects most humans population without clinical sign and symptoms worldwide. JCV causes the lethal demyelinating disease, progressive multifocal leukoencephalopathy (Padgett et al., 1971). About $90 \%$ of the adult population carries antibodies to the virus, and it seems that in most people, the virus remains latent (Knowles, 2006). High concentrations of JCV have been observed in urban sewage worldwide, therefore, it is suspected that the contaminated water is a typical route of JCV infection (Dias et al., 2018).

$\mathrm{JCV}$ is detected in the normal gastrointestinal tract and its complicity in colorectal cancer in humans (Toumi et al., 2017; Sinagra et al., 2014). JCV encodes three proteins that are the structural capsid proteins: VP1, VP2, and VP3 (Zheng et al., 2005). JCV also encodes the T antigen proteins (i.e., Large $\mathrm{T}$ and multiple small t splice variants) and the agnoprotein which is involved in the assembly of viral particles. T-Ag has several splice sites producing truncated proteins that are involved in regulating cell proliferation and viral transmission (Frisque, 2001). Based on nucleotide difference in VP1 region of the JCV, 8 genotypes and 14 subtypes was recognized (Caiqin et al., 2018). JCV genoptypes 1, 2, and 4 are distributed in Europe. Subtypes 3 and 6 are found in Africa, subtype 8 is found in Papua New Guinea and the Pacific Islands, and 
subtypes 2, 4, and 7 are found in Asia (Zanotta et al., 2013).

$\mathrm{T}-\mathrm{Ag}$ is capable of disrupting the function of tumor suppressor proteins $\mathrm{p} 53$ and members of the pRB family, which probably contributes to carcinogenesis in the animal models (Qian et al., 2000; Desjardins et al., 1997). The nucleic acid and T-Ag of JCV has been found in broad spectrum of human tumors such as esophageal carcinoma, colorectal cancer, anal carcinoma and gastric cancers (Del et al, 2005; Coelho et al., 2010; Link et al., 2009; Mou et al., 2012; Ramamoorthy et al.,2011; Shin et al., 2006). Based on experimental models, the human polyomaviruses JC (JCPyV) and BK (BKPyV) have been recently categorized by the International Agency for Research in Cancer as "possible carcinogens (Bouvard et al., 2012).

Studies on association of JCV and colorectal adenocarcinoma in Iran is limited, therefore, this study was conducted to evaluate the rate of JCV in patients with CRC in Ahvaz city. Ahvaz city is capital of khozestan province, located in the south west region of Iran.

\section{Ethic Consent}

The project was approved with approval number OG93141 by ethic committee of Ahvaz Jundishapur university of Medical Sciences, Ahvaz, Iran.

\section{Materials and Methods}

\section{Sample preparation}

A total of 120 formalin-fixed paraffin-embedded tissue blocks samples were collected from 40 (50\% male and $50 \%$ female) patients with CRC and 80 healthy control groups (40 male and 40 female) from Golestan and Imam Khomeyni hospitals in Ahvaz city, during 2004 to 2015. The sections of 5 microns thickness were prepared from each sample and stored at $4^{\circ} \mathrm{C}$ until DNA extraction.

Deparaffinization: Deparaffinization was done by xylene and ethanol (Germany, Merk). Initially, all the specimens were placed in microtubes then xylene was added and kept at $45^{\circ} \mathrm{C}$ for $15 \mathrm{~min}$ followed by centrifuge at $14,000 \mathrm{rpm}$. This stage was repeated again. The supernatant was discarded and $1 \mathrm{ml}$ absolute ethanol was added to precipitate and stored at the room temperature for $10 \mathrm{~min}$ and centrifuged again at 14,000 rpm for 1 minute. The supernatant was discarded. This process was repeated by adding $70 \%$ ethanol, followed the same condition. Finally supernatant was discarded and all microtubes were placed at $65^{\circ} \mathrm{C}$ for $5 \mathrm{~min}$ to vaporize the ethanol residue and the pellet was used in DNA extraction (Habibian et al., 2013 ).

\section{DNA extraction}

High pure PCR template preparation kit (Roche, Germany, code No: 11796828001) was applied for the extraction of DNA, according to the manufacturer's instruction. The extracted DNA was stored at $-70^{\circ} \mathrm{C}$ until PCR amplification.

\section{PCR amplification}

All the extracted DNA samples were initially subjected to $\mathrm{PCR}$ with consensus primers $\mathrm{PCO} 3 / \mathrm{PCO} 4$ ( $\beta$-globin) to confirm the quality of the extracted DNA (used as an internal control). The following primers (PCO3: 5' ACA CAACTGTGTTCACTAGC/PCO4: 5 CAACTTCAT CCACGTTCACC with PCR product of 110 bp (Shahab et al., 2015). For detection of JCV DNA by Nested PCR, the following primers and thermal programs were used. The specific primer P1 and P2 was used for amplification of JCV Vp1/T-Ag junction region of JCV (Tsuyoshi et al., 1995). The PCR reaction mixture consisted of PCR, $\mathrm{MgCl}_{2}(25 \mathrm{mM}) 2 \mu \mathrm{l}$, dNTP $(10 \mathrm{mM}) 0.5 \mu 1$, primers each $1 \mu \mathrm{l}$, taq polymerase(5unit) $0.3 \mu \mathrm{l}, \mathrm{D} / \mathrm{W} 12.5 \mu \mathrm{l}$, and template $7 \mu 1$. Based on the complete genome of JCV, accession NO; J02226.1. P1(VP1) -forward primer (outer) (2107-2127) 5'-TTTTGGGACACTAACAGGAGG-3' and P2- Reverse primers (outer) (VP1- Large T Ag)(27432762) 5'-AGCAGAAGACTCTGGACATG-3' was used with thermal condition as follow: initial denaturation at $94^{\circ} \mathrm{C}$ for 5 minutes, 35 cycles at $94^{\circ} \mathrm{C}$ for $1 \mathrm{~min}$, $52^{\circ} \mathrm{C}$ for $1 \mathrm{~min}, 72^{\circ} \mathrm{C}$ for $1 \mathrm{~min}$, and a final extension $72^{\circ} \mathrm{C}$ for $10 \mathrm{~min} .5 \mu \mathrm{l}$ of first round PCR products, was used for second round nested PCR. The following primers the inner forward primer (VP1) (2150-2172) 5'- CATATAACAAACACTGCCACAAC-3' and inner reverse primer (2696-2716) (VP1- Large T Ag) 5'- TGCTTTTCCCAGGTCTCAGAA -3 with the same PCR reaction mixture as described in the first round, was subjected to thermocyler (Teqlab, Germany) with thermal program as follow: initial denaturation at $94^{\circ} \mathrm{C}$ for $5 \mathrm{~min}$ followed by 35 cycles of denaturation at $94^{\circ} \mathrm{C}$ for $1 \mathrm{~min}$, annealing at $49^{\circ} \mathrm{C}$ for $1 \mathrm{~min}$, and extension at $72^{\circ} \mathrm{C}$ for $1 \mathrm{~min}$ and the final extension step at $72^{\circ} \mathrm{C}$ for $10 \mathrm{~min}$. All reactions performed in duplicate and along with the negative (distilled water) and positive controls.

\section{Gel electrophoresis}

The PCR products were separated on a $2 \%$ agarose gel and developed by Safe Stain under voltage at $100 \mathrm{~V}$. The result was seen under ultra violet in transilluminator. The first round PCR product was 656bp and second PCR products $567 \mathrm{bp}$ (Figure 1). The sizes of bands were compared with 100bp Ladder (Fermentas) which, was placed on the well as an indicator.

\section{Sequencing}

To confirm the results of PCR and to determine JCV DNA randomly 6 positive PCR products were selected and sequenced (Bioneer company, South Korea). The sequences were blasted using available databases https:// www.ncbi.nlm.nih.gov.

\section{Statistical analysis}

The obtained results were analyzed by the version 17 of SPSS software and the role of age and sex on positive cases were surveyed by the Fisher's exact and Chi square test.

\section{Results}

In this survey $4 / 40(10 \%)$ samples of CRC and $10 / 80$ (12.5\%) of control samples were positive for JCV DNA $(\mathrm{P}=0.69)$. The frequency of JCV was among the age group $>50$ years, $4 / 32(10 \%)$ compared to $<50$ years , $0 / 8$ $(\mathrm{p}=0.29) .3 / 4(7.5 \%)$ of male patients with $\mathrm{CRC}$ showed 


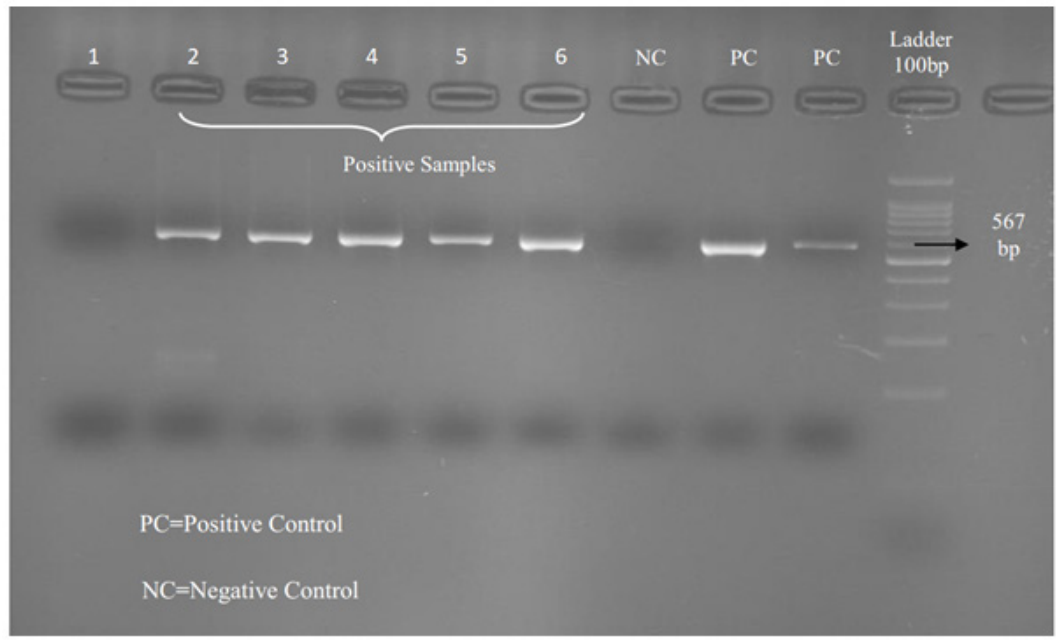

Figure 1. Results of JCV PCR in Patients with CRC. Line 1, Negative sample; Line 2-6, Positive samples; NC, Negative Control; PC, Positive sample; Molecular Marker (100bp size)

positive for JCV DNA while $1 / 4(2.5 \%)$ of female patients with CRC exhibited positive for JCV DNA ( $p=0.29)$. The rate of JCV in pathogenic stage, grade I, II was $0 / 4$ $(0 \%)$ while in grade III, IV $4(10 \%)$ was not significant $(\mathrm{p}=0.48)$. The distribution of JCV DNA in differentiation stage was WDAC $1(2.5 \%)$, MDAC $3(7.5 \%)$ and PDAC $(0 \%)(p=0.53)$.

Figure 1, shows the results of positive and negative samples by PCR. Table 1 shows the profile of patients with CRC positive and negative for JCV DNA.

Table 1. Shows the Number of Positive and Negative JCV in Tumors

\begin{tabular}{llll}
\hline Category & $\begin{array}{l}\text { JC virus } \\
\text { positive }\end{array}$ & $\begin{array}{l}\text { JC virus } \\
\text { negative }\end{array}$ & p Value \\
\hline Ages & & & \\
$\quad>50$ & $4(10 \%)$ & $28(70 \%)$ & 0.29 \\
$<50$ & - & $8(20 \%)$ & \\
Gender & $3(15 \%)$ & $17(85 \%)$ & 0.29 \\
$\quad \begin{array}{l}\text { Male } \\
\text { Female }\end{array}$ & $1(5 \%)$ & $19(95 \%)$ & \\
Colocteral & $4(10 \%)$ & $36(90 \%)$ & 0.69 \\
Adenocarcinoma & $10(12.5 \%)$ & $70(87.5 \%)$ & \\
Benign tumor & & & \\
Pathogenic stage & & $4(10 \%)$ & 0.48 \\
Grade I, II & - & $32(80 \%)$ & \\
Grade III, IV & $4(10 \%)$ & \\
Differentiation stage & & & \\
WDAC & $1(2.5 \%)$ & $5(12.5 \%)$ & 0.53 \\
MDAC & $3(7.5 \%)$ & $23(57.5 \%)$ & \\
PDAC & - & $8(20 \%)$ & \\
\hline
\end{tabular}

Table 1 shows the distributions of JC Virus DNA was among the age groups $(\mathrm{p}=0.29 \%)$, in gender $(\mathrm{p}=0.29 \%)$ in CRC and benign tumor $(\mathrm{p}=0.69)$, in pathology grade III, IV with histology grade I and II $(\mathrm{p}=0.48)$ and in Differentiation stage was not found significant $(\mathrm{p}=0.53 \%)$.

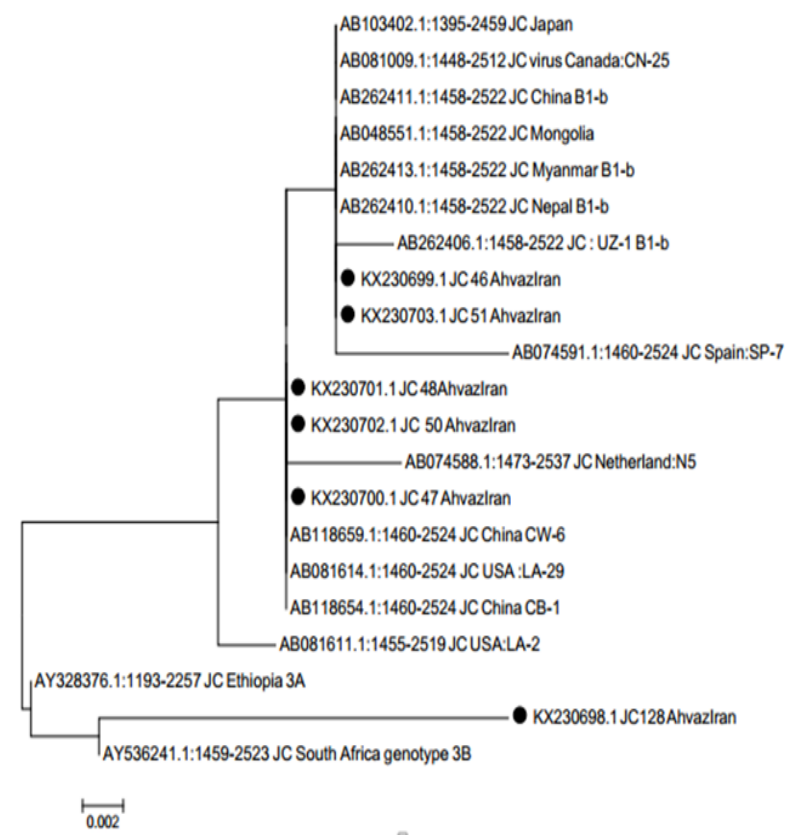

Figure 2. Phylogeny Tree was Constructed by Maximum Likelihood Method for JCV Vp1/T-Ag Junction Region of the Isolated JC virus Genomes with Accession Number KX230698- KX230703 Labeled by the Black Solid Circle. TThey were compared with different JCV $\mathrm{Vp} 1 / \mathrm{TAg}$ junction isolated from different regions of the world with accession numbers retrieved from Gen Bank. The isolated JC virus from Ahvaz, with accession number KX230698- KX230703 showed 99\% homology identity with different JC virus isolated from Japan, China, Mongolia, Uzbekistan, Spain, USA and Netherland. Scale Bar: 0.0002

The results of 6 sequences of the JCV Vp1/T-Ag junction region of the isolated JCV were deposited at GenBank under the accession numbers KX230698- KX230703. The MEGA6 and Maximum Likelihood method were used for phylogenetic analysis (Figure 2).

\section{Discussion}


Several factors including status of host genetic, immunodeficiency, geographically endemic patterns of $\mathrm{JC}$ virus infection, co-infection of $\mathrm{JC}$ virus and papillomavirus may lead to adenocarcinoma tumors (Shin et al., 2006; Yamaoka et al., 2009). CRC is one of dominant cause of death among man and women worldwide . High prevalence of $82 \%$ and $90 \%$ of JC virus associated with colorectal carcinoma have been reported in Portugal and USA respectively (Coelho et al., 2013; Shalaka et al., 2014). In the present study $10 \%$ of CRC of patients were positive for JCV DNA and was in agreement with results reported by Mou et al., (2012) in China. Sarvari et al., (2018) have reported low prevalence of $1.42 \%$ JCV DNA in patients with CRC, in Shiraz city, Iran, which was lower than our finding. In the present study the rate of JCV DNA was among the male (7.5\%) and female $(2.5 \%)$ patients $(\mathrm{p}=0.29 \%)$. Shalaka et al., (2014), depicted that the rate of JCV in male patients with $\mathrm{CRC}$ is higher than female. In the present study the frequency of JCV DNA among age group $>50$ years $(10 \%)$, and age group $<50$ years $(0 \%)(\mathrm{P}=0.29)$. Mou et al., (2012) have reported in China the frequency of JC DNA among the age groups was not found significant.

Investigations have revealed that almost half of gastric cancers samples were positive for JCV (Yamaoka et al., 2009; Shin et al., 2006). The concomitant JCV and human papillomavirus (HPV) have been reported. Twenty two anal cancers were tested by PCR for JCV and all were positive, while concomitantly 13 of the cases were positive for HPV (Ramamoorthy et al., 2011). These data demonstrate the presence of JCV throughout cancers of the digestive tract and suggest the possibility that JCV initiates cancers in these tissues.

it has been hypothesized that JC virus T-Ag could mediate metastasis in CRC cells through increased migration and invasion (Link et al., 2009)

In our present study the high frequency of $10 \% \mathrm{JCV}$ DNA have been found among the CRC specimens with grade III, IV. Mou et al., (2012) have detected the JCV DNA in CRC specimens with grade I, II, III, IV.

Several bacteria have been identified and implicated in the development of CRC. These include: Streptococcus bovis (Knudson, 2001), Helicobacter pylori (Moss et al., 1995), and Fusobacterium (Castellarin et al., 2012). Several viruses were suggested to be the risk factors for CRC. Among them, John Cunningham virus (JC virus), BK virus, Human Cytomegalovirus (CMV), Human papilloma viruses (HPV: particularly type 16 and 18) have the largest number of report (Vlado et al., 2013)

In the present study about 36/40 (90\%) samples showed negative for JC DNA. The role of mentioned bacteria and viruses have not investigated but requires further investigation.

Recent investigations revealed that, Infected patients with JC virus in immunodeficiency status may results in progress to PML, thus, treatment of patients infected with JC virus by rituximab natalizumab and efalizumab lead to progressive multifocal leukoencephalopathy (David et al., 2011; McGuigan et al., 2016; Schwab et al., 2012). Therefore, it is suggested that the urine of patients with CRC cancer or patients with autoimmune diseases should be screened for JC virus DNA before chemotherapy treatment or by immunomodulatory drugs (rituximab and natalizumab) therapy.

In summary, prevalence of JCV DNA was among 10\% patients with CRC and $12.5 \%$ benign tumors $(\mathrm{p}=0.69)$. The distribution of JCV DNA was among 7.5\% male and $2.5 \%$ female $(p=0.29)$. The frequency of JCV DNA was among $10 \%$ cases of age group $>50$ years and $0 \%$ of age group $<50$ years $(\mathrm{P}=0.29)$.

The subsequent T-Ag protein expression might explain the increased risk of colorectal cancer and requires further investigation. Recent investigations revealed that, Infected patients with $\mathrm{JC}$ virus in immunodeficiency status may results in progress to PML, thus, treatment of patients infected with JC virus by rituximab natalizumab and efalizumab lead to progressive multifocal leukoencephalopathy. Therefore, it is suggested that urine of patients with CRC cancer or patients with autoimmune diseases should be screened for JC virus DNA before chemotherapy treatment or by immunomodulatory drugs ( rituximab and natalizumab) therapy.

\section{Acknowledgments}

This study was a part of a research project conducted by, MSc student (virology), Mrs. Azadeh Haghi Navand with the registration number OG93141 financially supported by Infectious and tropical Diseases Research Center, Health Research Institute, Ahvaz Jundishapur University of Medical Sciences, Ahvaz, Iran.

\section{References}

Bouvard V, Baan RA, Grosse Y, et al (2012). Carcinogenicity of malaria and of some polyomaviruses. Lancet Oncol, 13, 339-40

Castellarin M, Warren RL, Freeman JD, et al (2012). Fusobacterium nucleatum infection is prevalent in human colorectal carcinoma. Genome Res, 22, 299-306.

Caiqin H, Ying H, Junwei S, et al (2018). Detection and analysis of variants of JC polyomavirus in urine samples from HIV1-infected patients in China's Zhejiang Province. Int Med Res, 46, 1024-32.

Coelho TR, Gaspar R, Figueiredo P, et al (2013). Human JC polyomavirus in normal colorectal mucosa, hyperplastic polyps, sporadic adenomas, and adenocarcinomas in Portugal. J Med Virol, 85, 2119-27

Coelho TR, Almeida L, Lazo PA, et al (2010). JC virus in the pathogenesis of colorectal cancer, an etiological agent or another component in a multistep process?. Virol J, 7, 42 .

David B, Clifford Beau A, Craig C, et al (2011). Rituximabassociated progressive multifocal leukoencephalopathy in rheumatoid arthritis. Arch Neurol, 68, 1156-64.

Dias J, Pinto RN, Vieira CB, et al (2018). Detection and quantification of human adenovirus (HAdV), JC polyomavirus (JCPyV) and hepatitis A virus (HAV) in recreational waters of Niterói, Rio de Janeiro, Brazil. Mar Pollut Bull, 133, 240-5.

Del VL, White M, Enam S, et al (2005). Detection of JC virus DNA sequences and expression of viral $\mathrm{T}$ antigen and agnoprotein in esophageal carcinoma. Cancer, 103, 516-27.

Desjardins P, Pilon AA, Hassell JA, et al (1997). Polyomavirus large $\mathrm{T}$-antigen binds the ' $\mathrm{pRb}$ related' protein $\mathrm{p} 130$ through 
sequences in conserved region2. Virus Res, 47, 85-90

Frisque RJ (2001). Structure and function of JC virus T' proteins. J Neurovirol, 7, 293-7.

Knowles WA (2006). Discovery and epidemiology of the human polyomaviruses BK virus (BKV) and $\mathrm{JC}$ virus (JCV). $A d v$ Exp Med Biol, 577, 19-45.

Knudson A (2001). Alfred Knudson and his two-hit hypothesis. (Interview by Ezzie Hutchinson). Lancet Oncol, 2, 642-5.

Link A, Balaguer F, Nagasaka T, et al (2014). Goel A. MicroRNA miR-J1-5p as a potential biomarker for JC virus infection in the gastrointestinal tract. PLoS One, 9, e100036.

Link A, Shin SK, Nagasaka T (2009). JC virus mediates invasion and migration in colorectal metastasis. PLoS One, $\mathbf{3}$, e8146.

McGuigan C, M Craner, J Guadagno, et al (2016). Stratification and monitoring of natalizumab-associated progressive multifocal leukoencephalopathy risk: recommendations from an expert group. J Neurol Neurosurg Psychiatry, 87, $117-125$

Moss SF, Neugut AI, Garbowski GC, et al (1995). Helicobacter pylori seroprevalence and colorectal neoplasia: evidence against an association. $J$ Natl Cancer Inst, 87, 762-3

Mou X, Chen L, Liu F, et al (2012). Prevalence of JC virus in Chinese patients with colorectal cancer. PLoS One, 7, e35900.

N Schwab, Ulzheimer JC, Fox RJ, et al (2012). Fatal PML associated with efalizumab therapy: Insights into integrin $\alpha \mathrm{L} \beta 2$ in JC virus control. Neurology, 78, 458-67.

Padgett BL, Walker DL, ZuRhein GM (1971). Cultivation of papova-like virus from human brain with progressive multifocal leucoencephalopathy. Lancet, 1, 1257-60

Qian W, Wiman KG (2000). Polyoma virus middle T and Small t. Antigens cooperate to antagonize p53 induced cell cycle arrest and apoptosis. Cell Growth Differ, 11, 31-9.

Ramamoorthy S, Devaraj B, Miyai K, et al (2011). John Cunningham virus $\mathrm{T}$-antigen expression in anal carcinoma. Cancer, 117, 2379-85.

Sarvari J, Mahmoudvand S, Pirbonyeh N (2018). Very low frequency of Epstein-Barr JC and BK viruses DNA in colorectal cancer tissues in Shiraz, Southwest Iran. Pol J Microbiol, 67, 73-9.

Shalaka S, Hampras F, Raphael P, et al (2014). Prospective study of seroreactivity to JC virus T-antigen and risk of colorectal cancers and adenomas cancer. Epidemiol Biomarkers Prev, 23, 2591-6.

Shin SK, Li MS, Fuerst F, et al (2006). Oncogenic T antigen of JC virus is present frequently in human gastric cancers. Cancer, 107, 481-8.

Sinagra E, Raimondo D, Gallo E, et al (2014). Could JC virus provoke metastasis in colon cancer?. World J Gastroenterol, 20, $15745-9$

Toumi W, Ripalti A, Ricciardiello L, et al (2017). Detection of a new JCV strain of genotype A in a subpopulation of colorectal adenocarcinomas in Tunisia. New Microbiol, 40, 99-106

Tsuyoshi K, Tadaichi K, Jing G, (1995). Parent-to-child transmission is relatively common in the spread of the human polyomavirus JC virus. J Clin Microbiol, 33, 1448-51.

Ugo Testa ID, Elvira P, Germana C (2018). Colorectal cancer: Genetic abnormalities, tumor progression, tumor heterogeneity, clonal evolution and tumor-initiating cells. Med Sci, 6, 31

Vlado A, Alexander S, Kent E, et al (2013). Significance of infectious agents in colorectal cancer development. $J$ Cancer, 4, 227-40.

World Cancer Research Fund/American Institute for Cancer Research (WCRF/AICR) (2018). Continuous Update Project Report Diet, Nutrition, Physical Activity and Colorectal
$J V$ Virus Incolon Cancer Type Adenocarcinoma

Cancer 2016. Revised 2018.London: World Cancer Research Fund International;. aicr.org/continuous-update-project/ reports/colorectal- cancer-2017-report.pdf. Accessed June 21, 2018.

Yamaoka S, Yamamoto H, Nosho K, et al (2009). Genetic and epigenetic characteristics of gastric cancers with JC virus T-antigen. World J Gastroenterol, 15, 5579-85.

Zaaimi, Y, Aparicio T, Laurent-Puig P, et al (2015). Advanced small bowel adenocarcinoma: Molecular characteristics and therapeutic perspectives. Clin Res Hepatol Gastroenterol, 40, 154-60.

Zanotta N, Delbue S, Rossi T, et al (2013). Molecular epidemiology of JCV genotypes in patients and healthy subjects from Northern Italy. J Med Virol, 85, 1286-92.

Zheng HY, Takasaka T, Noda K, et al (2005). New sequence polymorphisms in the outer loops of the JC polyomavirus major capsid protein (VP1) possibly associated with progressive multifocal leukoencephalopathy. J GenVirol, 86, 2035-45.

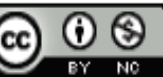

This work is licensed under a Creative Commons AttributionNon Commercial 4.0 International License. 